\title{
Divided societies, electoral polarisation and the Basque Country
}

\author{
Luis Moreno \\ Unidad de Políticas Comparadas (CSIC)
}

\section{Introduction}

Territorial politics in Spain can be regarded as the expression of a mode of multiple ethnoterritorial concurrence, which relates sub-state mobilisation with the interplay among central institutions and regions, or Comunidades Autónomas (Moreno, 1995). The 'historical nationality' [1] of the Basque Country has recently witnessed an increase in political terrorism carried out by ETA, as evidenced by party sectarian assassinations and actions throughout Spain. This course of action has further encouraged a division between Basque nationalists and autonomists [2] regarding proposals to eradicate political violence.

This paper briefly analyses relevant historical events in contemporary Basque Country with the purpose of framing the nature of the present political conflict. It reflects on recent developments that were triggered after the signing by the nationalist parties of the Pacto de Lizarra on September 12, 1998. It also examines the results of the latest Basque Elections held on May 13, 2001 and explores the future prospects for ending terrorism.

\section{Historical background}

The Basque Country is geographically situated at the Western end of the Pyrenees and covers territories in both Spain and France. The most populated area of Euskalherria [3] is located in Spain, which is a compound state incorporating nationalities and regions and various degrees of internal ethnoterritorial plurality.

Modern political unification of Spain took place by means of a dynastic union under the Catholic Kings in 1469 (Isabella of Castile and Ferdinand of Aragon). However, its constituent territories (crowns, kingdoms, principalities, dominions, provinces) maintained their autonomous existence. Aside from the incorporation of such territories, the Hispanic monarchy was achieved at an early stage of the European Modern Age, centuries before the processes of national homogenisation carried out by other European monarchies.

Prior to the union of the Catholic Kings, the Castilian princes achieved through conquests and royal marriages the unification of Leon and Castile (1230), as well as the incorporation of the Basque provinces of Gipuzkoa (1200), Araba (1332) and Biscay (1379). According to Salvador de Madariaga (1979) the three Basque provinces located in Spain were not constituent of the Basque Country. This has in fact been the result of a modern political creation. However all three provinces preserved their local rights or fueros, before and after they joined the Castilian Crown: "They would not recognised Lord or King without the prior and solemn pledge for honouring their fueros" (Pi i Margall, 1911: 251).

During the 19th Century, many territories of Spain, particularly those with a strong historical identity and tradition of self-government, perceived liberal centralism as unnatural and 
stifling. This, in turn, provoked these regions to demand the restitution of their fueros and control of local home rule. Navarre, the Basque provinces, and Catalonia contested homogenising attempts of centralist reforms most vehemently. The circumstances of the time ensured that the rebel Carlistas were able to benefit from the peripheral hostility towards government in Madrid.

After the Carlist defeats in the civil wars of 1833-40, 1846-48, and 1872-1875, the Basque Nationalist Party (Partido Nacionalista Vasco-Euzko Alderdi Jetzalea, PNV-EAJ), was founded in 1895 by an early Carlist himself, Sabino de Arana Goiri. In its early stages, Arana's nationalist proposals developed in the province of Biscay, not in the whole of the Basque Country, with the label of bizkaitarrismo. In 1893 Arana published Bizcaya por su independencia ('Independence for Biscay'). At the beginning of the 20th Century, the PNVEAJ was less successful in contesting elections in the Basque Country than the Catalanist Lliga in obtaining a class-wide support in Catalonia. This was due, at least partially, because of its religious focus and its ethnocentric claims.

Early Basque nationalism stressed traditional community values, which opposed the bourgeois industrial society. The effects of industrialisation involved a considerable influx into the Basque country of migrants from the rest of Spain. Primitive Basque mentality of a racist character was the ideological basis for early Basque nationalism. This ideology, combined with powerful populist elements and ethnoreligious exclusivity, produced a philosophy quite distinct from that of Catalan civic nationalism. Catalanism was more intellectual and less folkloric, and has always been less secessionist. It possibly provoked greater resistance than Basque nationalism because it offered an alternative view of Spain, something which the Basques frequently turned their back on. Overall, both forms of stateless nationalism can be perceived as manifestations of a strong periphery that contrasted to a weak and ineffective central state.

In spite of its short existence, the Second Republic (1931-39) contributed largely to the resolution of ethnoterritorial conflicts in Spain. The most notable improvement was the constitutional design of state as a regional model, situated somewhere between a unitary and a federal state. This led to the achievement of statutes of autonomy for Catalonia, the Basque Country and Galicia, the three 'historical nationalities'.

Three days after the proclamation of the Second Republic in 1931, an assembly of Basque mayors organised by José Antonio Aguirre, leader of the Basque Nationalist Party, claimed their right to autonomy and home rule within a Spanish federal republic, by the legendary Oak of Gernika. Months later, another assembly of mayors met in the city of Estella (Lizarra) and passed the proposal for a statute of autonomy, ratified also by the Navarran local councils and the Carlist representatives. However, parliamentary approval of the proposal by the Spanish Parliament was thornier than the Catalan statute. The most hotly contested issue of the inter-party negotiations had been the claims made by the Basque nationalists to establish an independent and bilateral relationship between Euskadi and the Vatican. Many Basque nationalists, fervent Catholics, resented the anti-clerical republican climate. They proposed an independent Concordat between the Basque Country and the RC Church. Note that at the end of 1931, the central government had decided to suspend 12 Basque newspapers because they were encouraging a popular uprising against civil authorities so that "[...] the interests of the Catholic religion could be defended" (Madariaga, 1979: 331).

A new statute project for the Basque country was prepared in 1932, but rejected by the Navarran local councils. By the end of the following year, the statutory project did not include Navarre and was supported in a referendum by 47 per cent in the province of Araba, and almost 90 per cent of Biscayans and Gipuzkoans. The proposal was put 
forward in the Spanish Parliament in December of 1933, but two years later it had still not been passed. After the left-wing victory of the Popular Front in the February 1936 elections, the members of parliament for the Basque Country presented the proposal approved by referendum in October 1933 once more to the Spanish Parliament. By the beginning of the Civil War, the Parliamentary Commission had practically completed its approval of the proposal. On 1 October 1936, the Basque Statute of Autonomy was passed, with similar rights and powers to that of Catalonia.

Representatives of all Republican parties were present at the ceremony of the appointment of José Antonio Aguirre as lehendakari, or president of the Basque autonomous government. At the same time, Manuel Irujo, representative of the PNV-EAJ, became member of the Spanish central government. Later on, during the Civil War (1936-39), "[...] Basque governmental officials behave as if they were running an independent state. Furthermore, they maintained secret bilateral contacts not only with Britain and the Vatican, but also with fascist Italy so that a separate armistice could be worked out [for the Basque Country]... However, after Franco took control of the territories in the Northern coast of Spain, the Basque leaders moved to Barcelona were they continued to participate in the Republican Government and to support the Republican Army [during the rest of the Civil War]" (Olábarri Gortázar, 1985: 135).

After the Civil War, the country fell firmly into the hands of a deeply centralist reactionary coalition, which had even 'imperialist' pretensions. The end of the dictatorship did not occur until General Franco died in 1975. Paradoxically, Franco's dictatorship provided the atmosphere necessary for today's regionalism, autonomism, and nationalism, although it remains true that, strictly speaking, separatism and federalism have older roots. The ability of sub-state nationalism to overcome ideological and political divisions manifested itself in cases of substantial consensus among the forces opposing the Francoism.

In the Basque Country, the secessionist guerrilla group ETA found considerable popular support, and given the oppressive political circumstances during Franco's dictatorship, it became intertwined with the democratic movement. In 1973, ETA assassinated Admiral Carrero Blanco, Franco's Prime Minister, appointed by the dictator to become his political heir. Those who then advocated political violence against the Franco dictatorship were not regarded without sympathy by many sectors of the population at large, and not only in the Basque country but also in the rest of Spain. With the advent of liberal democracy, many of these people would eventually distance themselves from ETA and the intensification of its actions. The military nucleus of ETA continued to insist that the militants of the Basque national liberation movement were the only victims of police torturers and of representatives of centralist oppression. Gradually, ETA adopted an anti-Spanish stance and aimed at imposing, by means of political violence, a view of an independent Basque Country where nationalism and socialism would go hand in hand. This minority view conflicted with the notion of an Estado de las Autonomías put forward by the democratic Constitution of 1978.

The Spanish 1978 Constitution was made possible by a wide inter-party agreement. Conservatives, Centrists, Nationalists, Socialists and Communists ended up hammering out an agreement for the implementation of the federalising Estado de las Autonomías. The accepted solution took the form of an unwritten pledge to extend the procedures of political dialogue and consociationalism into the future. This open model of asymmetrical federalisation did not presuppose the ways and means by which the different 'historical nationalities (Basque Country, Catalonia, Galicia) and regions could finally be articulated (Moreno, 2001).

On 6 December 1978, the Spanish Constitution received in popular referendum 87.9 per cent 'yes 'votes, 7.8 per cent 'no' votes, and 4.3 per cent null or blank votes. As many as 
32.9 per cent of the registered electoral abstained from voting. The 'outlyer' territory in the general pattern of massive support for the 1978 Constitution was the Basque Country. In two of the three 'historical territories' (Gipuzkoa and Biscay), abstention reached 56 per cent of the registered electorate, but a majority of 67 per cent of the total turnout in the Basque Country voted 'yes' for the 1978 Constitution. [4] These figures have been subjected to much speculation. The abstention percentage in Gipuzkoa and Biscay has been interpreted as a manifestation of the limited extent of the Spanish state's legitimacy in Euskadi, something which could have given incentive to the continuation of ETA's terrorism and the intensification of political violence since the transition to democracy (Linz et al, 1986; Conversi, 1997). [5]

\section{Twenty years of home-rule-all-round}

During the period 1978-2000, Spain has undergone a widespread process of political devolution and home-rule-all-round. The level of self-government reached by the Spanish Comunidades Autónomas is high as compared with most of the decentralised countries in the world. For instance, the final budgetary say in the running of $a b$ novo programmes and policies implemented by the Spanish nationalities and regions is entirely autonomous. This usually implies the setting of budgetary priorities within the aggregate of policies and services to be complied statutorily. Certainly, the Basque Country and Navarre with a system of fiscal quasi-independence have been able to fund more generously their policies. The financial system of concierto allow them to collect main taxes such as income tax, corporation tax and VAT and, since 1997, those corresponding to 'special taxes' (petrol, tobacco and spirits). Indeed, Basque and Navarran institutions collect practically all taxes. Subsequently, they transfer a previously agreed quota to the Spanish central treasury. These transfers represent compensation for Spanish common expenditure, and to cover the costs of running those state administrative bodies. Consequently, the per capita level of public expenditure in the Basque Country is much higher as compared to the Spanish mean. Note that as compared with the autonomous public spending in Catalonia, the Basque per capita expenditure is 1,8 higher. [6]

In general, it can be said that the territorial re-allocation of public spending in the last twenty years, following the deep process of decentralisation and devolution of power to the nationalities and regions, has been impressive. Table 1 illustrates the significant increase in regional expenditures since the approval of the 1978 Constitution.

In the case of the Basque Country, the degree of home rule is highest among all the Spanish Comunidades Autónomas, and comes close to what could be considered the classical tenets of a modern sovereign state. In fact, other political communities within multinational states have made explicit their desire to reach the level of self-government similar to that which the Basque Country has achieved. [7]

Nationalist parties in Spain (PNV and CiU) have been active not only as regards the quest to secure higher degrees of home rule for their own power bases, but also in the general governance of Spain as a whole. The agreements reached between the PP (Spanish Government) and the Basques (PNV), Canary (CC) and Catalan Nationalists (CiU) during the term of office 1996-2000 are very illustrative in this respect. Let us remind that in such a period the PP minority Government needed extra support at the Spanish Parliament.

The territorialisation of politics in Spain has manifested itself in the proliferation of regionally-based parties (Pallarés et al, 1997). [8] Internal asymmetries in Spain have also expressed themselves in a wide and varied mosaic of political parties. This is not a hindrance for parties with country-wide aspirations. But even political organisations receiving state-wide public support have structured themselves in line with the federal 
texture of Spain. This aspect brings about a further element of 'pork barrel politics' [9] to a system where the territorial dimension has become decisive.

During this period of home-rule-all-round, the situation in the Basque Country has been highly conditioned by political violence and, in particular, by an intensification of the terrorist strategy carried out by ETA. [10] Such a course of action has followed the actionrepression-action spiral first deployed by ETA during late Francoism, and which aimed at consolidating a counter-state and counter-society --the latter of some numerical significance-- operating with their own laws and code of conduct (Letamendía, 1994). As a reaction to this strategy of violence, a Basque democratic inter-party platform in search for consociational solutions to achieve peace was articulated. During the period 1988-98, all major democratic parties operating in the Basque Country set up the Pacto de Ajuria Enea with the aim of co-ordinating their policies against terrorism. This Pact was in line with the societal reaction against ETA's terrorism (Llera, 2000).

In 1998 the leadership of the Basque Nationalist Party believed the timing was right to attempt to 'democratise' political supporters of ETA, thus bringing them into the realm of a non-violent path towards Basque nation-building and eventual independence. ETA regarded this move by the PNV as a confirmation of its own ultimate aspiration for secession, and as an opportunity to influence PNV's political strategy in the Basque Country.

On 12 September 1998 the Pacto de Lizarra (Estella), inspired by the 1998 Good Friday Agreement in Northern Ireland, was signed by the Basque nationalist parties (Partido Nacionalista Vasco, Herri Batasuna, later transformed into Euskal Herritarrok, and Eusko Alkartasuna). EzkerBatua, the Basque federated organisation of the Spanish coalition Izquierda Unida (United Left) also signed the Pact. Both the Basque organisations of the main Spanish political parties (PP and PSE-EE/PSOE) did not participate in such a forum, nor did the anti-nationalist Unidad Alavesa.

The main claim of the Lizarra Pact was to articulate a political negotiation with the Spanish central state on issues of political sovereignty, territoriality and self-determination. The Pact was signed a few days prior to the declaration of a unilateral truce by ETA.

After the Lizarra Pact, political dialogue and negotiation among the Basque political forces themselves, and these with the central government, has proved to be difficult. Meanwhile, the results of the 1998 Basque elections, held on 25 October 1998, had produced a somewhat stalemate political situation. The cease-fire declared by the Basque terrorists on September 1998 was unilaterally revoked fourteen months later. Such an announcement opened up a new situation of political instability and tension for both political parties and citizenship at large. Shortly after, there was an increase in ETA terrorism with outright killing of representatives of the non-nationalist parties, mainly PP and PSE-EE members. Such action has dramatically polarised the political situation in the Basque Country.

The strategy of sectarian terrorism deployed by ETA can be regarded as a prolonged attempt aimed at breaking the mould of Basque dual self-identification. This is a societal feature not only characteristic of the Basque Country, but of Spain's plural ethnoterritorial composition, which helps to understand the degree of internal consent and dissent in decentralized Spain, and which is briefly analysed in the following section.

\section{Dual identity and compound nationality}

The case of Spain shows the lack of a single and all-embracing national state identity extended throughout the country. Spain's multiple ethnoterritorial identities expressed in the 
Spanish 'historical nationalities' (Basque Country, Catalonia, Galicia) and regions [11] are indicative that the problems derived from a lack of internal accommodation correspond not only to the countries that have recently achieved independence. In fact, the persistence of a dual identity or compound nationality reflects the ambivalent nature of internal ethnoterritorial relations that have existed within Spain throughout its long and dense history.

The concept of dual identity or compound nationality concerns the way in which citizens identify themselves in sub-state nations or regions. It incorporates in variable proportions the regional (ethnoterritorial) ascriptive identity and the national (state) identity. As a result of this, citizens share their institutional loyalties at both levels of political legitimacy without any apparent fracture between them. [12]

The quest for self-government by meso-level communities is in full accordance with the variable manifestation of such duality in citizens' self-identification: the more the primordial regional (ethnoterritorial) identity prevails upon modern state identity, the higher the demands for political autonomy. Conversely, the more developed the national (state) identity is, the less likely it would be for ethnoterritorial conflicts to arise. At the other extreme, complete absence of one of the two elements of dual identity would lead to a deep socio-political division. If this were the case, demands for self-government would probably take the form of a claim for outright sovereignty and independence. In other words, when citizens in a sub-state community identify themselves in an exclusive manner, the institutional outcome of such antagonism will also tend to be exclusive (Moreno, 1986).

The consistency in the results provided by periodical surveys on dual identity in Spain is to be underlined. Note that the Basque Country and the Canary Islands are the two Comunidades Autónomas were single regional/ethnoterritorial identity is higher than 20 per cent (26.8 per cent and 21.7 per cent, respectively). However, and in a survey immediately carried out before the 2001 Basque Elections, those who declared to feel 'only Basque' were 23 per cent of the total, whereas 41 per cent identified themselves "as Basque as Spanish".[13]

In Galicia, Catalonia, Balearic Islands and Asturias, single regional self-identification is higher than 10 per cent of the total of survey respondents. Spanish single identity is more significant in Castile-La Mancha. 'Don't Know/No answer' figures are considerably low as compared to the usual percentages produced in this kind of surveys. This finding seems to confirm the lack of indifference among Spaniards on the cultural and institutional implications of self-identification and the process of decentralization. The only exception is the Basque Country (6 per cent), where political violence has an obvious impact on selfidentification (see Table 2).

Some Spanish Comunidades Autónomas may be labelled as 'exclusivist' as the cases of the Basque Country and Canary Islands clearly show. In these, the level of single ethnoterritorial identity is noticeably higher. This reflects a degree of identity polarisation, which has recently developed even more intensely in the Basque Country, by the delineation of two partisan blocs between those who call themselves --and vote for-nationalist and those who do not. These labels are somewhat ambiguous. In the 2001 Basque Elections (briefly analysed below) some sections of the non-nationalist bloc (also called 'autonomist' or 'constitutionalist') sought to emphasise electoral messages making nationalism and secession analogous concepts. In the nationalist camp (PNV-EA), messages put forward by the lehendakari Juan José Ibarretxe insisted that Euskadi is a country for all residents of the Basque Country. This statement counteracts the message put forward by some EH activists and ETA supporters, that immigrants from other Spanish regions and residents of the Basque Country were not to be given the right to vote in an 
eventual referendum for independence.

Many nationalist voters have repeatedly proclaimed that they do not want the Basque Country to secede from the rest of Spain (see Table 3). At the same time they want the Basque Country to enjoy a high degree of political autonomy which would preserve its political distinctiveness within a democratic Spain, and a European Union where mesocommunities should have greater say in the running of public affairs (Keating, 1998; Moreno, 1999). Note that only around a fifth of the PNV voters were in favour of full independence for the Basque Country. Xabier Arzallus, leader of the PNV, is of the opinion that with just 51 per cent of 'yes' votes' in a hypothetical referendum for independence it would be enough to secede from Spain. In such a situation the PNV would expect its voters to vote in favour of independence. However, the same day this statement was made to the media, Iñaki Anasagasti, leader of the PNV parliamentary group at the Spanish Parliament in Madrid expressed a contrary view by saying that, "[...] it would be politically absurd to propose an independent Basque Country in a united Europe" (El País, 14 Dec., 99). Both viewpoints reflect the ambivalent stance of the PNV towards this delicate issue. A clear approach in either of the two directions would unequivocally alienate sections of PNV voters.

Full independence is not a viable option for the Basque and Spanish populations at large (see Table 4). However, the considerable support for this option among Basque respondents is to be highlighted (i.e. a quarter of the total surveyed population). This translates into a critical support for ETA's strategy to further polarise Basque society and -what is crucial to understand-- to divide it into two separate communities with divergent attitudes, perceptions and beliefs. If this strategy were to succeed, an irreparable fracture in Basques' dual identity would be the preamble for open civil warfare as witnessed in deeply divided societies (e.g. ex-Yugoslavia or Northern Ireland).

Self-determination of the kind advocated by the Basque Nationalist Party (PNV) does not preclude the survival of dual identities and compound nationalities. It mainly refers to the preservation of an autonomous sphere of political power free from interference by Spanish central institutions. It remains to be seen whether this sophisticated manner of reconciling civic integration and political independence can survive those brutal and desperate attempts by ETA to provoke a civil confrontation among the Basque people.

\section{The 2001 Basque Elections}

The results of the Basque Elections held on May 13, 2001 have reflected a polarisation of voters' preferences into two blocs of similar electoral weight: nationalist and non-nationalist. As shown in Table 5, in no other previous Basque elections have the two blocs been as close to each other in electoral support. In 1998, nationalist parties (PNV-EAJ, Eusko Alkartasuna, and Euskal Herritarrok) collected fewer votes (54.5 per cent) as compared to the 1994 elections (56.3 per cent). In 2001, votes cast for the nationalist parties decreased to 53.2 per cent of the total, whereas the non-nationalists obtained 46.8 per cent of the vote. [14] The trend indicates a narrowing of electoral preferences for either of the two blocs. An interpretation of this electoral shift can be made as if the Basque electorate sought to avoid a clear victory of one camp over the other. In other words, this electoral polarisation would have served the purpose of preventing political imposition of the victorious over the defeated.

Not surprisingly, the preferred solution for a future Basque government as expressed by the voters prior the celebration of the 2001 Elections was a Basque executive comprised of a coalition of nationalists and non-nationalists and, in particular, between PNV/EA and PSEEE. Furthermore, a priority for the Basque government to re-build the unity among all 
democratic political parties [15] (nationalists and non-nationalists) was considered to be the first priority (54 per cent of all surveyed Basques prior the celebration of the 2001 Elections), with a greater support than the second priority of "...finishing with ETA" (50 per cent, Survey by Demoscopia reproduced in El País, May 7, 2001).

The voter turnout in the 2001 Elections was highest in Basque elections since 1980. This was most likely a consequence of the hotly-contested electoral campaign. The significance of this fact has to do with alleged claims of fears and, of a 'democratic deficit'. It simply refutes the presumption that a higher voter turnout would benefit the non-nationalist bloc. In line with this way of thinking, many non-nationalist voters had been reluctant to vote at the Basque elections because --mainly-- in some rural areas voters were intimidated by the social pressure exerted by ETA supporters. This inhibiting climate, which was the result of political violence, had been regarded as the main factor explaining why voter turnout for the Basque Elections was lower than for the Spanish General Elections (see Table 6). [16]

Overall, the most significant result of the 2001 Basque Elections was the decline of Euskal Herritarrok (EH), the coalition sponsored by ETA. This follows a rejection by a majority of Basques to accept ETA's strategy of terrorism to achieve its political goals. Note that EH representation in the Basque Parliament of Vitoria-Gasteiz was reduced by 50 per cent (from 14 MPs in 1998, to 7 MPs in 2001). The popular vote for EH dropped dramatically from 17.8 per cent, in 1998, to 10.1 per cent. Undoubtedly, there was an almost linear transfer of votes from EH to the coalition formed by PNV and EA. This can be interpreted as a political statement against the sectarian killings carried out recently by ETA, by those who identify themselves as nationalists but do not want a Basque nation built on assassinations and extortion. Clearly there is a large majority of Basques that want to avoid a societal fracture that could lead to civil confrontation (Jaúregui, 1996).

The clear victory of the PNV/EA coalition can be interpreted not only as support for a coalition of democratic nationalist parties but also as a reaction against the Spanish media campaign which portrayed PNV and EA as 'demons', or as being 'the same' as ETA. The aggressive campaign of the PP in the Basque Country, where it hoped to win the elections after the signing of a "Pact for the Liberties" with the PSOE, also contributed to produce an electoral 'backlash'. As has often been the case in Spain since the transition to democracy, nationalists in the three 'historical nationalities' (Basque Country, Catalonia and Galicia) have gained support in elections by portraying themselves as 'victims' of political attacks by the central state. According to such discourse, the embodiment of 'Madrid' as the external adversary giving cohesion to all party political nationalism has proved to be a powerful instrument to achieve electoral success (Solé Tura, 1985; Moreno, 1986).

There are various and open-ended scenarios for the future of the Basque Country. There is no doubt that political uncertainty will remain highly conditioned by ETA's terrorism. It is evident that after the 2001 Elections the level of tension between the two blocs (nationalist and non-nationalist) has been significantly reduced. Notwithstanding, the Spanish Premier, José María Aznar (PP), has made it clear that there is no place for self-determination outside the constitutional procedures established to reform the Basque Statute of Autonomy and the provisions of the 1978 Spanish Constitution. Some nationalist leaders have insisted on an alternative a la irlandesa ('Irish via') in a voluntaristic manner. Such an option cannot dismiss the many dissimilarities between the case of the Basque Country and Northern Ireland (political violence being the one common feature). What remains to be seen is whether consensual politics and consociational practices can return to the Basque Country. Certainly, such practices have had a positive impact in the past. 
[1] The Constitution of 1978 recognises three 'historical nationalities'; the Basque Country, Catalonia and Galicia. In general, it is not easy to distinguish conceptually the term 'nationality' from that of 'nation'. Such a terminological distinction was to a great extent a consequence of the dichotomy between 'nation-state' and 'state of the nationalities' as regards the cases of the Austria-Hungary and Ottoman Empires at the beginning of the 20th century. In broad terms, nationality can be referred to as a minority nation which has acceded to a degree of institutional autonomy or independence within a multinational state and which concurs or co-exists with a majority nation and/or other ethnoterritorial groups (cf. Krejcí and Velímsky, 1981; Lecours, 2000).

[2] By nationalists we refer to those parties that explicitly declare themselves as such and have as an ultimate --although in some cases vague-- aim the achievement of independence for the Basque Country. Autonomists are those political formations that assume political home rule for the Basque Country along the lines of the 1978 Constitution (on occasions they also label themselves as 'constitutionalists'). Among the former PNV (Basque Nationalist Party), EA (Basques' Reunion) and EH (Ourselves, the Basque People) are the prominent political formations. In the latter PSE-EE (Basques socialists federated with the Spanish PSOE), Basque PP (regional organisation of the Spanish Popular Party), UA (Unidad Alavesa, foralist provincial party in Araba) and Ezker Batuallzquierda Unida (United Left) could be included.

[3] This is the name given to the lands where Euskera (Basque language) is spoken. For Basque nationalism Euskalherria is an ethnoterritorial nation made up of the Spanish 'historical territories' (provinces) of Araba, Gipuzkoa, Biscay, as well as Navarre and the French districts of Labourd (Lapurdi), Soule (Zuberoa) and Lower Navarre (Behenafarroa) in the département of the Atlantic Pyrenees.

[4] Note that the PNV was in favour of an 'active abstention'. The 'Yes' votes in the whole of the Basque Country amounted to $31.3 \%$ of the registered electorate (Linz et al, 1986).

[5] Subsequently, the Statute of Autonomy of the Basque Country was also approved in popular referendum in 1979 . As many as $88 \%$ of those who voted ( $61 \%$ of the registered electorate) gave support to it. Once again, these figures have made activists and sympathisers of ETA to point out that the Statute is not legitimate because it received the support of less than $50 \%$ of the eligible votes.

[6] According to 1995 data, the mean non-financial per capita spending carried out by Catalonia and Galicia was 228,378 Ptas., which compared to 417,256 Ptas in the Basque Country.

[7] For instance, and after the first post-apartheid democratic elections in the Republic of South Africa held in 1994, Mangosuthu Buthelezi, political chief of the Inkhata Freedom Party, advocated for the province of KwaZulu-Natal the same degree of home rule as enjoyed by the Basque Country in Spain.

[8] After the 1999 regional elections, the political map of the Spanish Estado de las Autonomias was substantially modified. A higher degree of heterogeneity in the composition of the three-tier system of government was further introduced. At the meso-level, the PP controlled 9 Comunidades Autónomas, in coalition with regional forces in two of them (Canary Islands and Navarre). Six other Communities had PSOE governments in coalition with other parties, mainly nationalist or regionalist (Andalusia, Aragon, Balearic Islands). Finally, a coalition of nationalists (PNV and EA) governed the Basque Country, and CiU was trying to form government with the support either of the PP or the ERC (centre-left independentists).

[9] This expression should not be understand only as a mere illustration of the practices of politicians and government officials to dip for 'pork', or funds for regional and local projects, from the national treasury. It also implies the support from regional parties sought by national parties to stay in power at the central state.

[10] A third of all the assassinations by ETA occurred during the critical period of transition to democracy (1978-80). A second wave of terrorism coincided with the formation of the a nationalist/non-nationalist coalition government by PNV and PSE (Llera, 2000).

[11] These are: Andalusia, Aragon, Asturias, Balearic Islands, Canary Islands, Cantabria, Castile and Leon, Castile-La Mancha, Extremadura, Galicia, La Rioja, Murcia, Navarre and Valencia.

[12] The question put to them in successive surveys ${ }^{3}$ was as follows: "In general, would you say that you feel...1. Only Basque, Catalan, Galicia, etc.; 2. More Basque, Catalan, Galician, etc., than Spanish; 3. As much Basque, Catalan, Galician, etc. as Spanish; 4. More Spanish than Basque, Catalan, Galician, etc.; 5. Only Spanish; 6. Don't know; 7. No answer". 
[13] The aggregate percentages of those with a degree of dual identity were $61 \%$ as compared to $28 \%$ of those declaring a single or exclusive self-identification (i.e. "only Basque" or "Only Spanish"). Note that among PNV voters, a third declared to be "Only Basque", the same amount of those who identify themselves "As Basque as Spanish" (El País, May 7, 2001).

[14] These percentages translated into $40 \mathrm{MPs}$ and $35 \mathrm{MPs}$ for nationalists and non-nationalists, respectively. Less than 90,000 votes separated the two blocs (the total cast votes were 1,400,000, approximately).

[15] As it has to some extent occurred with the Pacto de Ajuria Enea between1988-98. The re-elected lehendakari made it explicit that no new inter-party forum for the search of peace would include parties that had not condemned ETA's terrorist killings (El País, May 16, 2001).

[16] As a matter of fact the turnout in the Basque in the 2000 General Election was only of $63.8 \%$.

Table 1: Territorial Distribution of Public Expenditure in Spain (\%)

$\begin{array}{lccccccc} & 1981^{1} & 1984 & 1987 & 1990 & 1992 & 1997 & 2000^{2} \\ \text { CENTRAL } & 87.3 & 75.6 & 72.6 & 66.2 & 63.0 & 59.5 & 54 \\ \text { REGIONAL } & 3.0 & 12.2 & 14.6 & 20.5 & 23.2 & 26.9 & 33 \\ \text { LOCAL } & 9.7 & 12.1 & 12.8 & 13.3 & 13.8 & 13.6 & 13\end{array}$

${ }^{1}$ Beginning of the process of devolution

2 Government's estimates

Source: Spanish Ministry of Public Administrations (MAP, 1997).

\section{Table 2: Self-identification by Spanish Comunidades Autónomas (1990-95)}

A. Vertical percentages (click here to print)

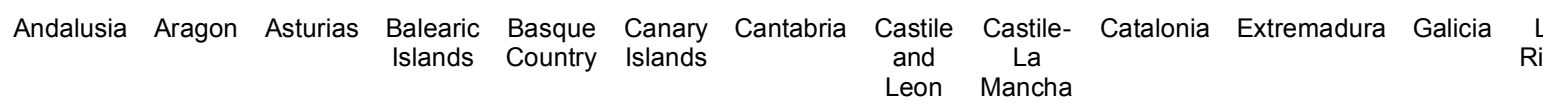

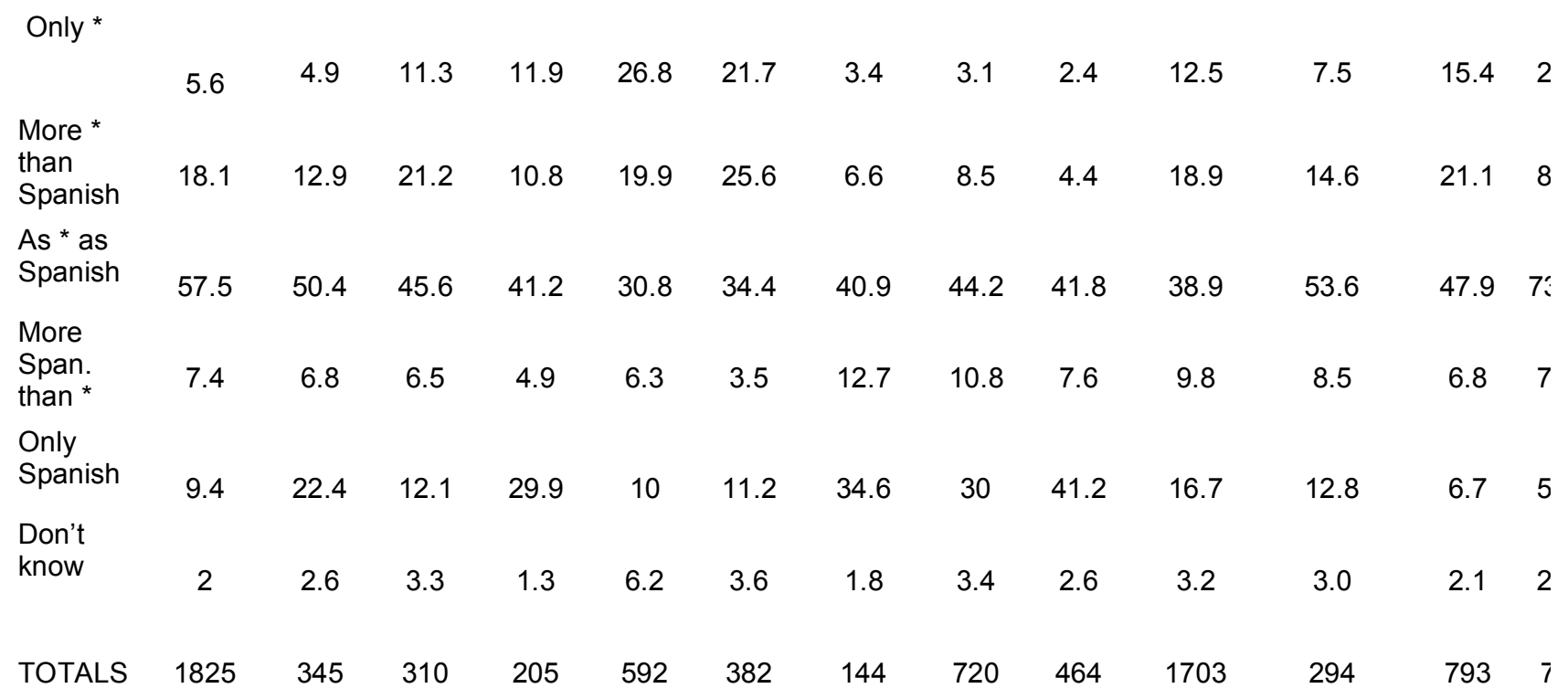

* = Basque, Catalan, Galician... 
B. Aggregated vertical percentages ${ }^{1}$ (click here to print)

$\begin{array}{cccccccc}\text { Andalusia Aragon Asturias Balearic } & \begin{array}{c}\text { Basque } \\ \text { Islands }\end{array} \text { Country } & \text { Canary } & \text { Islands } & \text { Cantabria } & \begin{array}{c}\text { Castile } \\ \text { and }\end{array} & \begin{array}{c}\text { Lastile- Catalonia Extremadura Galicia } \\ \text { Leon }\end{array} \text { Mancha } & \text { Li }\end{array}$

\begin{tabular}{|c|c|c|c|c|c|c|c|c|c|c|c|c|}
\hline $\begin{array}{l}\text { Single } \\
\text { identity }\end{array}$ & 15 & 27.3 & 23.4 & 41.8 & 36.8 & 32.9 & 38 & 33.1 & 43.6 & 29.2 & 20.3 & 22.1 \\
\hline $\begin{array}{l}\text { Dual } \\
\text { identity }\end{array}$ & 83 & 70.1 & 73.3 & 56.9 & 57 & 63.5 & 60.2 & 63.5 & 53.8 & 67.6 & 76.7 & 75.8 \\
\hline $\begin{array}{l}\text { Regional } \\
\text { identity }\end{array}$ & 23.7 & 17.8 & 32.5 & 22.7 & 46.7 & 47.3 & 10 & 11.6 & 6.8 & 31.4 & 22.1 & 66.5 \\
\hline $\begin{array}{l}\text { Equal } \\
\text { identity }\end{array}$ & 57.5 & 50.4 & 45.6 & 41.2 & 30.8 & 34.4 & 40.9 & 44.2 & 41.8 & 38.9 & 53.6 & 47.9 \\
\hline $\begin{array}{l}\text { Spanish } \\
\text { identity }\end{array}$ & 16.8 & 29.2 & 18.6 & 34.8 & 16.3 & 14.7 & 47.3 & 40.8 & 48.8 & 26.5 & 21.3 & 13.5 \\
\hline $\begin{array}{l}\text { Don't } \\
\text { know }\end{array}$ & 2 & 2.6 & 3.3 & 1.3 & 6.2 & 3.6 & 1.8 & 3.4 & 2.6 & 3.2 & 3.0 & 2.1 \\
\hline TOTALS & 9346 & 1808 & 1634 & 1041 & 3584 & 2021 & 761 & 3764 & 2372 & 9126 & 1519 & 4574 \\
\hline
\end{tabular}

Notes to (B): $\quad$ Single identity includes 'Only *' and 'Only Spanish'.

Dual identity includes 'More * than Spanish', 'As * as Spanish' and 'More Spanish than *'.

Regional identity includes 'Only *' and 'More * than Spanish'

Equal identity includes 'As * as Spanish

Spanish identity includes 'Only Spanish'

Source: Elaboration by Moreno, Arriba and Serrano (1998) on CIRES data (1990-95). *

Table 3: Preferences for the territorial organisation in the Basque Country (percentage of voters)

Centralised

Autonomy as current

More autonomy

Independence

"Don't knows"

(N)

Basque Country
6
34
22
19
19
1,615

PNV
5
33
35
18
8
309

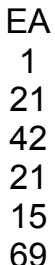

HB

$\overline{2}$

9

83

5

$69 \quad 143$

Source: Spanish Centro de Investigaciones Sociológicas and Pallarés et al(1997: Table 10).

Table 4: Preferences concerning the form of the state among Basque (1998) and Spanish (1996) respondents.

Centralism

Autonomy

Federalism

Independence

$$
\text { Basques (1998) \% }
$$

Spaniards (1996) \%

16

44

21

8 
Don't know/No answer

$(\mathrm{N})$
9

1,600
11

2,500

Source: Llera (2000, Table 2). .

Table 5: Nationalist and non-nationalist voting blocs in the Basque Regional Elections (1980-2001)

\begin{tabular}{|c|c|c|c|c|c|c|c|}
\hline YEAR & 1980 & 1984 & 1986 & 1990 & 1994 & 1998 & 2001 \\
\hline Nationalist & 596,971 (a) & 704,952 & $776,706(b)$ & 670,919 (b) & 575,629 (c) & 679,829 & 747,320 \\
\hline (\%) & 67.4 & 66.0 & 68.3 & 67.6 & 56.5 & 55.0 & 53.2 \\
\hline $\begin{array}{l}\text { Non- } \\
\text { nationalist }\end{array}$ & $\begin{array}{c}288,912 \\
(\mathrm{e})\end{array}$ & $\begin{array}{c}363,352 \\
(\mathrm{e})\end{array}$ & $\begin{array}{c}360,709 \\
(\mathrm{e})\end{array}$ & $\begin{array}{c}321,926 \\
(\mathrm{e})\end{array}$ & $\begin{array}{l}442,730 \\
\text { (f) }\end{array}$ & $\begin{array}{l}555,744 \\
\text { (f) }\end{array}$ & $\begin{array}{c}658,729 \\
(\mathrm{~g})\end{array}$ \\
\hline
\end{tabular}

$\begin{array}{llllllll}(\%) & 32.6 & 34.0 & 31.7 & 32.4 & 43.5 & 45.0 & 46.8 \\ \text { Turnout (\%) } & 59.8 & 68.5 & 69.6 & 61.0 & 59.7 & 70.3 & 79.0\end{array}$
(a) PNV--HB--EE
(b) PNV--HB--EE--EA
(c) PNV--EA--HB/EH 89-93-96-00).
(f) PSE/EE--PP--IU--UA
(g) PSE/EE--PP/UA--IU

(d) PNV--EA (Note: HB/EH did not contest)

(e) PSE/PSOE--PP--UCD/CDS--PCE/IU (In 1977, PSOE includes also PSP + PSOE (h) + ASD.// PP corresponds to AP+GU (1977), UFVP (1979), CP (1982-86) and PP (1989) // UCD/CDS relates to UCD + DCV + DIV (1977), UCD (1979), and CDS (1986-89)// PCE/IU accounts for PCE (1977-79-82) and IU (1986-

Note: Votes for other minor parties have been discarded.

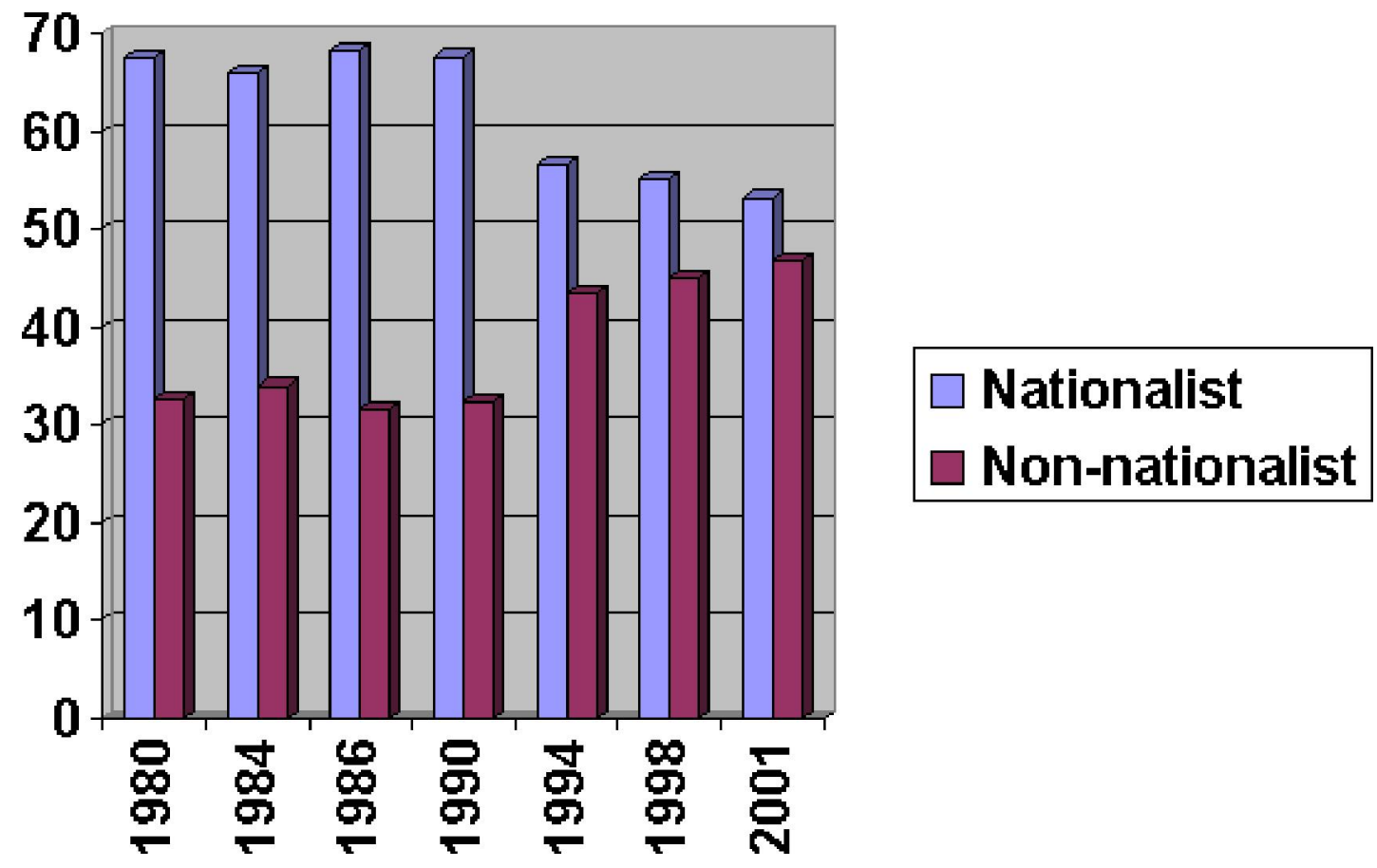

Source: Own elaboration of data provided by the Department of Political Science, University of the Basque 
Table 6: Nationalist and non-nationalist voting blocs in the Spanish General Elections (Basque Country) (1977-2000)

\section{YEAR}

Nationalist

(\%)

Non-

nationalist

(\%)

Turnout (\%)
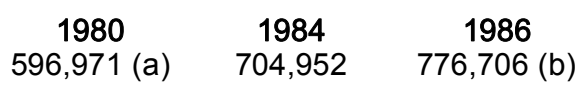

1990
670,919 (b)

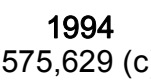

1998
679,829

2001

747,320

\section{4}

68.3

67.6

$360,709(\mathrm{e}) \quad 321,926(\mathrm{e})$

56.5
442,730 (f)

55.0

555,744 (f)

53.2 $658,729(\mathrm{~g})$

32.6

34.0

31.7

32.4

43.5

45.0

46.8

59.8

68.5

69.6

61.0

59.7

70.3

79.0

(a) PNV--HB--EE (In 1977, HB votes correspond to ANV+ESB)

(b) PNV--HB--EE--EA

(c) PNV--EA--HB/EH

(d) PNV--EA (Note: HB/EH did not contest)

(e) PSE/PSOE--PP--UCD/CDS--PCE/IU (In 1977, PSOE includes also PSP + PSOE (h) + ASD// PP corresponds to AP+GU (1977), UFVP (1979), CP (1982-86) and PP (1989) // UCD/CDS relates to UCD + DCV + DIV (1977), UCD (1979), and CDS (1986-89)// PCE/IU accounts for PCE (1977-79-82) and IU (1986/89/93/96/00).

(f) PSE/EE--PP--IU--UA

(g) PSOE--PP--IU

Note: Votes for other minor parties have been discarded.

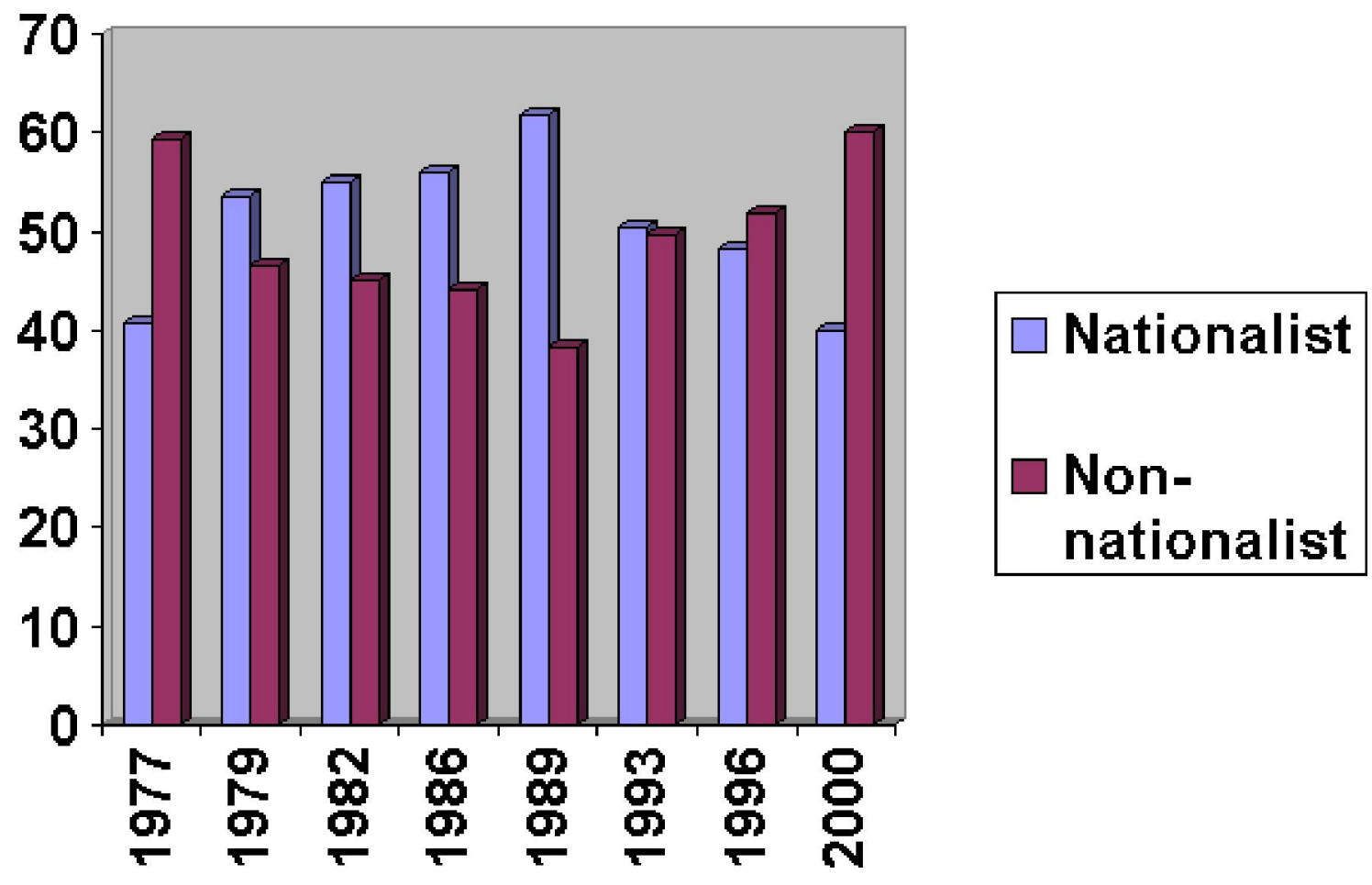

Source: Own elaboration on data provided by the Department of Political Science, University of the Basque Country. * 


\section{Bibliography}

Conversi, Daniele (1977), The Basques, the Catalans and Spain. Alternative Routes to Nationalist Mobilisation. London: Hurst \& Co.

Jaúregui, Gurutz (1996), Entre la tragedia y la esperanza: Vasconia ante el nuevo milenio. Barcelona: Ariel.

Keating, Michael (1998), The New Regionalism in Western Europe. Territorial Restructuring and Political Change. Cheltenham: Edward Elgar.

Krejcí, J. and Velímsky, V. (1981), Ethnic and Political Nations in Europe. London: Croom Helm.

Lecours, André (2000), "Ethnonationalism in the West: A Theoretical Exploration," Nationalism and Ethnic Politics, 6, pp.103-124.

Letamendía, Francisco (1994), "On Nationalisms in Situations of Conflict (Reflections from the Basque Case", in Beramendi, J.R. et al (eds.), Nationalism in Europe. Past and Present, pp. 247-275 (Vol. I). Santiago: Universidad de Santiago de Compostela.

Linz, Juan José et al (1986), Conflicto en Euskadi. Madrid.

Llera, Francisco J. (2000), "Basque polarization: Between Autonomy and Independence", in Safran, W. and Máiz, R. (eds.), Identity and Territorial Autonomy in Plural Societies, pp. 101-120. London. Frank Cass.

Madariaga, Salvador (de) (1979), España: Ensayo de Historia Contemporánea (14 ${ }^{\text {th }}$ edition). Madrid: EspasaCalpe.

MAP (1997), Estudio sobre reparto del gasto público en 1997 entre los distintos niveles de administración. Madrid: Ministerio de Administraciones Públicas.

Moreno, Luis (1986), Decentralisation in Britain and Spain: The Cases of Scotland and Catalonia. Ph.D. thesis, University of Edinburgh.

__ (1995), 'Multiple Ethnoterritorial Concurrence in Spain', Nationalism and Ethnic Politics, Vol. 1, No. 1, pp. $11-32$.

- (1999), "Local and Global: Mesogovernments and Territorial Identities," Nationalism \& Ethnic Politics, $3 \& 4$, pp.61-75.

__ (2001), The federalization of Spain (Spanish Ed. :1997). London: Frank Cass.

Moreno, Luis; Arriba, Ana And Serrano, Araceli (1998), 'Multiple Identities in Decentralized Spain: The Case of Catalonia', Regional \& Federal Studies, Vol. 8, No. 3, pp. 65-88.

Olábarri Gortázar, Ignacio (1985), "Un conflicto entre nacionalismos: La 'cuestión regional' en España, 18081939", in Fernández Rodríguez, F. (ed.), La España de las Autonomías, pp. 71-143. Madrid: Instituto de Estudios de Administración Local.

Pallarés, F.; Montero, J.R. and Llera, F.J. (1997), 'Non State-wide Parties in Spain: An Attitudinal Study of Nationalism and Regionalism', Publius. The Journal of Federalism, Vol. 27, No. 4, pp. 135-169.

Pi i Margall, Francesc (1977), Las nacionalidades $\left(4^{\text {th }}\right.$ edition; $1^{\text {st }}$ ed.: 1876). Madrid: Librería de los Sucesores de Hernando, 1977.

Solé Tura, Jordi (1985), Nacionalidades y nacionalismos en España. Autonomías, federalismo, autodeterminación. Madrid: Alianza. 
Paper presented at the Colloquium Advancing peace in Ethnically Divided Societies, IPSA Research Committee on 'Politics and Ethnicity', Queen's University, Belfast, 25-28 July 2001.

4 [CSIC] [UPC] [Working Papers] 